\title{
Police Use of ConduCTEd ENERgy WeAPons: A REVIEW OF THE CANADIAN JURISPRUDENCE
}

\author{
VLADIMIR A ZAYCHENKO* AND SIMON N VERDUN-JONES**
}

This article analyzes the current Canadian legal framework that governs the deployment of conducted energy weapons (CEWs), such as tasers, and explores the ongoing public debate concerning its use in Canada. The tragic case of Robert Dziekanski's death at the Vancouver International Airport raised concerns about the use of CEWs and triggered important changes in the CEW policies across Canada. Both the Kennedy and Braidwood Commission Reports have led to restrictions on the use of CEWs. In light of these reports, this article provides some insight into the nature and scope of criminal and civil litigation involving police use of the CEW. It highlights the perception of the CEW as a weapon reserved for use only in the absence of other less forceful options. This article also identifies the various grounds for bringing criminal charges and/or civil suits against individual officers, local governments, and manufacturers.
Cet article analyse le cadre juridique canadien actuel qui régit le déploiement des «armes à impulsions», comme les pistolets Taser, et explore le débat public en cours sur leur utilisation au Canada. La mort tragique de Robert Dziekanski à l'aéroport international de Vancouver soulève des questions au sujet de l'utilisation de ces armes et a amené d'importants changements dans les politiques à ce sujet à travers le pays. Les Rapports Kennedy et Braidwood ont tous les deux amené des restrictions sur l'utilisation de ces armes. À la lumière de ces rapports, cet article fournit un aperçu de la nature et de la portée des poursuites criminelles et civiles impliquant l'utilisation des armes à impulsion par la police. Il souligne la perception que ces armes sont des armes dont l'utilisation est permise uniquement dans l'absence d'autres options moins violentes. Cet article définit aussi les divers motifs de poursuites criminelles ou civiles contre des membres individuels de la police, des gouvernements locaux, et des fabricants.

\section{TABLE OF CONTENTS}

I. INTRODUCTION .................................... 149

II. USE OF THE CONDUCTED ENERGY WEAPON IN

APPREHENDING SUSPECTS IN CANADA $\ldots \ldots \ldots \ldots \ldots \ldots \ldots \ldots$

III. THE CONDUCTED ENERGY WEAPON AS A LESS-THAN-LETHAL

ForCE NECESSARY TO APPREHEND A SUSPECT . . . . . . . . . . . 156

IV. EXCESSIVE USE OF THE CONDUCTED ENERGY WEAPON AND

Legal Mechanisms of Police Accountability . . . . . . . . . . . 165

V. Conclusion .................................. 174

\section{INTRODUCTION}

While law enforcement agencies initially embraced the conducted energy weapon (CEW) for its promise of safe, effective, and less lethal control of resisting suspects, it did not take long for various communities and interest groups to raise profound concerns over its potential abuse. Consequently, it is hardly surprising that a wave of litigation has emerged in which it has been alleged that, in certain circumstances, the deployment of the CEW should be categorized as an excessive and, therefore, wrongful use of force. Police executives are currently facing the challenge of developing appropriate CEW policies and training programs to preserve it as a less lethal option. This article analyzes the current Canadian legal

PhD (Law), Samara State University; PhD Candidate (Criminology), School of Criminology, Simon Fraser University.

JSD, Professor, School of Criminology, Simon Fraser University. 
framework that governs the deployment of the CEW and, more broadly, explores the ongoing public debate concerning its use in Canada.

A brief review of national headlines during the past few years highlights the persistence of public controversy surrounding the use of the CEW, culminating in October 2007 with a highly publicized incident at the Vancouver International Airport, during which Robert Dziekanski died shortly after being shocked with a taser by Royal Canadian Mounted Police (RCMP) officers. ${ }^{1}$ This tragic case increased concerns about the appropriateness of employing the $\mathrm{CEW}$, stirred public outrage, and triggered important changes in CEW-related policies.

Dziekanski's case, although unique in its impact, is hardly uncommon. In southern New Brunswick, RCMP officers used "a stun gun against a woman who allegedly held a knife and chased her estranged husband into a Sussex barber shop." In Red Deer, the family of a "man who died after police shocked him several times with a stun gun has filed a wrongful death lawsuit worth $\$ 1.7$ million. The suit alleges negligence by the US-based stun gun company Taser, the RCMP, three RCMP officers, the local health region, a civilian who allegedly helped police, a hospital, two doctors and two paramedics.”3 In April 2010, a 73-year-old man was tasered by an RCMP officer and a Metro Vancouver transit police officer after being arrested under the Mental Health Act. ${ }^{4}$ Both officers have later been charged with both assault and assault with a weapon and suspended with pay pending the outcome of the investigation. ${ }^{5}$ During June 2010, in Collingwood, Ontario, a 27-year-old man died "after being shocked with a stun gun by Ontario Provincial Police.”

To the law-abiding public, media images such as these have created a gulf of suspicion and mistrust regarding a tool that seems unfamiliar and potentially dangerous. Citizens often see the CEW as being used in situations where even non-compliant or merely argumentative persons are forced to obey any demands made by a police officer armed with a taser.

In this atmosphere of public mistrust, legal challenges surrounding the use of the CEW are inevitable. Instances of police taser misuse may have even more far-reaching repercussions. As Commissioner Thomas Braidwood noted in his Phase 2 Report on the circumstances of Dziekanski’s death: "Mr. Dziekanski’s death appears to have galvanized public antipathy for the Force and its members. That is regrettable, because the most important weapon in the arsenal of the police is public support."

"Security video of Robert Dziekanski,” CBC News (28 March 2008), online: CBC News <http://www. cbc.ca/news/background/tasers/video.html>.

2 "Controversy over RCMP use of Taser on Sussex woman," CBC News (5 February 2009), online: CBC News <http://www.cbc.ca/news/canada/new-brunswick/story/2009/02/05/nb-taser-sussex.html> .

3 "Family of Alberta man who died after stun gun shocks files lawsuit," CBC News (11 September 2008), online: CBC News <http://www.cbc.ca/news/canada/calgary/story/2008/09/11/doan-lawsuit.html>. RSBC 1996, с 288.

“B.C. police charged after Taser used on man, 73” CBC News (25 October 2010), online: CBC News $<$ http://www.cbc.ca/news/canada/british-columbia/story/2010/10/25/bc-taser-surrey-rcmp-assault.html> . “OPP Taser stun precedes man's death,” CBC News (25 June 2010), online: CBC News <http:// www.cbc.ca/news/canada/toronto/story/2010/06/25/tor-taser-collingwood.html>.

Braidwood Commission on the Death of Robert Dziekanski, Why? The Robert Dziekanski Tragedy, (Vancouver: Library and Archives Canada Cataloguing in Publication, 2010) at 14, online: Commissions of Inquiry <http://braidwoodinquiry.ca/report/P2Report.php> [Braidwood Commission Report, Part 2]. 
Understandably, reported instances of deaths associated with the use of the CEW have captured the attention of the media and the public, resulting in calls in some jurisdictions to place a moratorium on the use of the taser. ${ }^{8}$ Both the Kennedy ${ }^{9}$ and Braidwood ${ }^{10}$ Commissions' reports have led to the RCMP and some municipal forces imposing restrictions on the use of CEWs in an attempt to appropriately locate the CEW within their use of force continua. These attempts continue to be hampered by a lack of information concerning its risks and benefits, as well as by an incomplete or misguided understanding of how the courts have begun to shape the legal landscape surrounding the use of the CEW by law enforcement agencies. Yet the Kennedy Commission specifically recommends that " $[t]$ he RCMP should continue to be involved in and stay abreast of current independent research on the use and effects of the CEW."11

This article is designed to provide some insight into the nature and scope of current and future criminal and civil litigation involving police use of the CEW. It highlights the changing perception of the CEW as a weapon that should be used with the utmost care and only in the absence of other less forceful options, and it traces the emergence of the current view that police should resort to the CEW only in those situations where a threat of grievous bodily harm or death makes its deployment justifiable. The article also identifies the various grounds for bringing criminal charges and/or civil suits against individual officers, as well as for holding local governments and manufacturers legally accountable for the perceived violation of human rights.

In conducting searches on legal databases, it was determined that it would be appropriate to limit research on the CEW to the taser. Although other hand-held stun guns, stun belts, and projectile-deploying CEWs can be used by law enforcement agencies, the background readings on the topic have indicated that the taser is the dominant CEW on the market and is the device currently used by RCMP, municipal, and provincial police forces in Canada.

The taser was designed as a pain-compliance device with its origins dating back to the late 1960s. The first model, called Tasertron Taser, was patented in the United States in 1974 by Jack Cover. ${ }^{12}$ Currently TASER International, Inc, an American company, holds the rights to the Taser name and technology. It manufactures a number of taser models targeting both the civilian and law enforcement markets, including the M26 and X26 models currently employed by Canadian law enforcement agencies. Despite somewhat different technical specifications, both models are functionally very similar. M26 is an older model, first introduced in 1999. It is a larger, heavier device than the X26 model, which was introduced

Amnesty International Canada, Amnesty International's concerns about Tasers (17 December 2008), online: Amnesty International Canada <http://www.amnesty.ca/themes/tasers_backgrounder.php>

Commission for Public Complaints Against the Royal Canadian Mounted Police (CPC), Report Following a Public Interest Investigation into a Chair-Initiated Complaint Respecting the Death in RCMP Custody of Mr. Robert Dziekanski (Ottawa: Commission for Public Complaints Against the Royal Canadian Mounted Police, 2009), online: CPC <http://www.cpc-cpp.gc.ca/prr/rep/rev/chairpre/dziekanski/index-eng.aspx $>$ [Kennedy Commission Report].

10 Braidwood Commission on Conducted Energy Weapon Use, Restoring Public Confidence: Restricting the Use of Conducted Energy Weapons in British Columbia (Vancouver: Library and Archives Canada Cataloguing in Publication, 2009), online: Braidwood Inquiry <http://www.braidwoodinquiry.ca/report/ P1Report.php> [Braidwood Commission Report, Part 1].

$11 \quad$ Kennedy Commission Report, supra note 9 at 206.

12 Braidwood Commission Report, Part 1, supra note 10 at 49. 
in 2003. ${ }^{13}$ Both models resemble a pistol weapon and can be used either in push-stun mode (the device is pressed against the target's body, emitting a pulsed electrical current directly into the muscles) or in probe mode (a pulsed electrical current is transmitted into the target's body via two metal-wired darts that are launched using a compressed nitrogen blast when the trigger is pulled). When used in the probe mode, each of the two probes must penetrate both the target's clothing and the outer layer of skin in order to establish a circuit. Each push of the trigger delivers a five-second electrical current cycle which can be repeated if the trigger is pressed again, or extended if pushed continuously. ${ }^{14}$ The device generates a series of 40 microsecond pulses at a rate of up to 20 pulses per second. It uses four different colourcoded, single-use cartridges carrying probes with wires of different length (from 15 to 35 feet) and is capable of generating a maximum voltage of 50,000 volts. ${ }^{15}$ Although there are different specifications with respect to electrical currents, both models "have an almost identical ‘delivered charge’ for each pulse — approximately 100 micro-coulombs,” which is considered to be the best indicator of the potential electrostimulation. ${ }^{16}$ According to the experiments conducted for the Braidwood Commission inquiry by Patrick Reilly, an applied physics expert from John Hopkins University, "human subjects, who were subjected to brief high-voltage pulses on their forearms ... reported pain on average at 0.5 micro-coulombs, and intolerable pain at 1.0 micro-coulombs. This is to be contrasted to the delivered charge of 100 micro-coulombs from each pulse of a conducted energy weapon, which delivers 95 pulses over a five-second period." ${ }^{17}$

Given its evident potential to achieve compliance through both pain and incapacitation, the taser has quickly become a weapon of choice among the many other options available to police officers. TASER International, Inc reported that " 350,000 officers in 12,750 agencies in more than 40 countries use their weapon, with nearly 550,000 actual field uses."18 The manufacturer markets the device as a safer alternative to other weapons, claiming that its use "reduces officer injuries, reduces subject injuries, reduces the incidence of resorting to lethal force, and reduces professional standards complaints alleging excessive force."19 Such claims, however, should be approached with caution. It is not surprising that the use of the $\mathrm{CEW}$ in place of other weapons or techniques has reduced the number of workplace injuries reported by police officers since these weapons allow officers to control suspects from a distance without having to engage in the hand-to-hand struggles that typically cause injuries. ${ }^{20}$

Another line of reasoning, which suggests that use of the CEW will reduce the incidence of lethal force encounters, is both problematic and speculative. As noted in Part I of the Braidwood Commission Report: "[i]f the advent of conducted energy weapons has resulted

\author{
Ibid at 50 \\ Ibid at 51 . \\ Ibid at 52 . \\ Ibid at 55 . \\ Ibid at 56. \\ Ibid at 272. \\ Ibid. \\ See e.g. Emma Jenkinson, Clare Neeson \& Anthony Bleetman, "The Relative Risk of Police Use-of- \\ Force Options: Evaluating the Potential for Deployment of Electronic Weaponry” (2006) 13 Journal of \\ Clinical Forensic Medicine 229; Michael R Smith et al, “The Impact of Conducted Energy Devices and \\ Other Types of Force and Resistance on Officer and Suspect Injuries” (2007) 30:3 Policing: An \\ International Journal of Police Strategies \& Management 423.
}


in fewer subjects being shot by police officers, one would expect that change to be reflected in police-shooting data." ${ }^{21}$ However, existing statistics with respect to the number of policeshooting deaths in British Columbia between 1992 and 2007 do not corroborate that. Similar conclusions have been reported by the analysis of RCMP data conducted under the auspices of the Commission for Public Complaints Against the RCMP. Moreover, a large-scale American study not only confirmed that the number of incidents of in-custody deaths does not drop following the introduction of CEWs but also reported a statistically significant increase in deaths in the first full year following their deployment. Researchers have attributed these findings to the "liberal use" of tasers in the first months of their deployment and the possibility that this trend led to the escalation of some confrontations to the point that resort to firearms became necessary. ${ }^{22}$

Unfortunately, the relative ease with which the taser can be deployed as well as the misconception that it is a safer alternative to other weapons may well encourage excessive use by law enforcement personnel.

The potential for excessive use of CEWs has several dimensions. CEWs can be used too frequently, that is, at inappropriately low levels of suspect resistance. They can also be used too repetitively: "Reported deaths in association with [CEWs] often involve multiple activations of a Taser (more than one Taser at a time) or multiple 5 second cycles from a single Taser." 23 This article will demonstrate how the Canadian jurisprudence on the use of CEWs is evolving in an attempt to balance the risks and benefits of CEWs.

\section{USE OF THE CONDUCTED ENERGY WEAPON IN APPREHENDING SUSPECTS IN CANADA}

Police officers have a duty to preserve the peace and to prevent crime. ${ }^{24}$ On occasion, that duty requires the use of force up to, and including, lethal force. Officers are outfitted with weapons, including pistols with hollow-jacketed bullets, oleoresin capsicum(OC) spray, and conducted energy devices; they are trained to use them when they deem it appropriate to do so. The preventative use of force has become a widespread phenomenon in many countries in the modern age. In the appropriate circumstances, the use of both lethal and less-thanlethal/non-lethal force is an accepted practice in Canada.

Before proceeding with an analysis of the current legal framework governing the use of the CEW by police, it is imperative to draw a distinction between two fundamentally different situations. The first is that of a police officer employing a CEW device in circumstances that do not present a clear threat to human life. The second is that of deploying

$21 \quad$ Braidwood Commission Report, Part 1, supra note 10 at 279.

22 Ibid at 281, citing the American study: Byron K Lee et al, "Relation of Taser (Electrical Stun Gun) Deployment to Increase in In-Custody Sudden Deaths” (2009) 103:6 The American Journal of Cardiology 877 at 879.

23 Michael R Smith et al, “A Multi-Method Evaluation of Police Use of Force Outcomes, Executive Summary” (July 2010) at 14, online: National Criminal Justice Reference Service (NCJRS) <http:// www.ncjrs.gov/pdffiles1/nij/grants/231177.pdf>.

24 These are common law duties that have been defined in Rice v Connolly, [1966] 2 QB 414 at 419: duties "necessary for keeping the peace, for preventing crime or for protecting property from criminal injury ... the duty to detect crime and to bring an offender to justice.” See also Dedman $v R$, [1985] 2 SCR 2 [Dedman]. 
the device in circumstances that may pose a significant threat to life: for example, when the CEW is applied to a suspect's chest or, as in the case of Dziekanski, when there are multiple deployments of the CEW, thereby inducing a life-threatening hyperadrenergic state. The conditions in these two situations are undoubtedly different, as are the justifications. In this article, the focus is primarily fixed upon the former situation as the CEW is objectively considered to fall within the spectrum of less-than-lethal/non-lethal force ${ }^{25}$ and is normally used as such. However, given the continuous debate about the safety of the CEW and its potential to inflict life-threatening injuries, ${ }^{26}$ a brief discussion of the legal framework surrounding the second situation also seems to be appropriate.

Section 25(3) of the Criminal Code, ${ }^{27}$ together with subsections (4) and (5), justify employing the CEW under circumstances that may objectively endanger life insofar as the measures taken constitute a level of "force that is intended or likely to cause death or grievous bodily harm.”

25(3) Subject to subsections (4) and (5), a person is not justified for the purposes of subsection (1) in using force that is intended or is likely to cause death or grievous bodily harm unless the person believes on reasonable grounds that it is necessary for the self-preservation of the person or the preservation of any one under that person's protection from death or grievous bodily harm.

(4) A peace officer, and every person lawfully assisting the peace officer, is justified in using force that is intended or is likely to cause death or grievous bodily harm to a person to be arrested, if

(a) the peace officer is proceeding lawfully to arrest, with or without warrant, the person to be arrested;

(b) the offence for which the person is to be arrested is one for which that person may be arrested without warrant;

(c) the person to be arrested takes flight to avoid arrest;

(d) the peace officer or other person using the force believes on reasonable grounds that the force is necessary for the purpose of protecting the peace officer, the person lawfully assisting the peace officer or any other person from imminent or future death or grievous bodily harm; and

(e) the flight cannot be prevented by reasonable means in a less violent manner.

(5) A peace officer is justified in using force that is intended or is likely to cause death or grievous bodily harm against an inmate who is escaping from a penitentiary within the meaning of subsection 2(1) of the Corrections and Conditional Release Act, if

See e.g. $R$ v Leeson, 2008 ONCJ 720, [2008] OJ no 5506 (QL) at para 16 [Leeson].

In light of developments in US courts, TASER International, Inc has issued an advisory to the effect that the weapon should not be deployed in the chest area (thereby implicitly admitting its potential danger if the electrodes are close to the heart). See TASER International, Inc, News Release, "TASER Training Bulletin 15.0 Regarding Medical Research Update and Revised Warnings” (15 October 2009), online: FBI National Academy Associates < http://www.fbinaa.org/files/public/TaserTraining_Bulletin_MEMO 
(a) the peace officer believes on reasonable grounds that any of the inmates of the penitentiary poses a threat of death or grievous bodily harm to the peace officer or any other person; and

(b) the escape cannot be prevented by reasonable means in a less violent manner. ${ }^{28}$

Provincial legislation that defines policing services and the powers and duties of police officers contains corresponding provisions. For example, according to an Ontario regulation issued under the Police Services Act, ${ }^{29}$ police officers may use lethal force if they believe "on reasonable grounds, that to do so is necessary to protect against loss of life or serious bodily harm.”30

This protection is analogous to the self-defence provisions found in section 34 of the Criminal Code. However, section 25(3) permits police officers exercising their lawful authority to use lethal force to preserve not only themselves, but also someone under their protection. Persons under their protection might include those who are threatened by an assailant, including fellow police officers, and those in the officer's custody. In $R v$ Nasogaluak, ${ }^{31}$ the Supreme Court of Canada considered the application of section 25(3) and held that it "prohibits a police officer from using a greater degree of force, i.e. that which is intended or likely to cause death or grievous bodily harm, unless he or she believes that it is necessary to protect him- or herself, or another person under his or her protection, from death or grievous bodily harm" and stated that "[t]he officer's belief must be objectively reasonable." ${ }^{32}$ It is significant, however, that the Supreme Court emphasized: "[p]olice actions should not be judged against a standard of perfection. It must be remembered that the police engage in dangerous and demanding work and often have to react quickly to emergencies." 33 The Court, therefore, stated that police "actions should be judged in light of these exigent circumstances." 34

Section 25(4) of the Criminal Code authorizes a police officer making a lawful arrest to employ reasonable force, including lethal force, such as shooting a suspect (or applying the CEW at his/her chest to prevent the suspect's flight from arrest). However, this provision only applies in the face of an imminent or future threat of death or grievous bodily harm to some person and when no less-violent means of capture are available.

It should be noted, however, that Canadian law enforcement agencies have never viewed the CEW as a lethal option and have never trained its officers to respond to situations that call for protection from imminent or future death or grievous bodily harm with the use of a $\mathrm{CEW} .{ }^{35}$ It is therefore hardly surprising that the issue has not been raised in Canadian courts. This is certainly not to say that sections 25(3)-(5) cannot be applied to the use of CEWs in

Ibid, ss 25(3)-(5).

RSO 1990, c P.15 [Ontario Police Act].

Equipment and Use of Force, RRO 1990, O Reg 926, s 9.

2010 SCC 6, [2010] 1 SCR 206 [Nasogaluak, SCC], aff'g 2007 ABCA 339, 422 AR 222 [Nasogaluak, CA].

Nasogaluak, SCC, ibid at para 34

Ibid at para 35.

Ibid.

House of Commons, Standing Committee on Public Safety and National Security, Evidence (12 February 2009) at 1035 (Chair: Garry Breitkreuz), online: Parliament of Canada <http://www.parl.gc.ca/House Publication/Publication.aspx?DocId=3676580\&Language=E\&mode=1\&Parl=40\&Ses=2\#T0905>. 
the appropriate circumstances: however, as long as the CEW continues to be perceived as a non-lethal/less-than-lethal weapon, these Criminal Code provisions are of limited applicability. It is difficult to imagine a situation in which a police officer having a lethal weapon at his/her disposal would resort to the deployment of a taser with a specific intent to protect against the loss of life or serious bodily harm.

\section{THE CONDUCTED ENERgy WeAPON AS A LESS-THAN-LETHAL FORCE NECESSARY TO APPREHEND A SUSPECT}

The use of the CEW as a measure of force that does not, under normal conditions, pose a danger to human life or threaten grievous bodily harm is justified by the need to effect an arrest. Ensuring the arrest of a suspect is an appropriate objective that justifies the use of such force. This does not present a clear danger to human life; therefore, the interest of bringing a suspect to justice, as well as the preservation of order through general deterrence, provide sufficient justification for employing such non-lethal force.

In Canada, police use of force is constrained by the provisions of sections 25 and 27 of the Criminal Code.

Section 25(1)(b) and (c) of the Criminal Code sets out a justification for police use of force, providing as follows:

25(1) Every one who is required or authorized by law to do anything in the administration or enforcement of the law

(a) as a private person,

(b) as a peace officer or public officer,

(c) in aid of a peace officer or public officer, or

(d) by virtue of his office,

is, if he acts on reasonable grounds, justified in doing what he is required or authorized to do and in using as much force as is necessary for that purpose. ${ }^{36}$

Section 27 justifies the use of force to prevent certain offences from being committed:

27 Every one is justified in using as much force as is reasonably necessary

(a) to prevent the commission of an offence

(i) for which, if it were committed, the person who committed it might be arrested without warrant, and 
(ii) that would be likely to cause immediate and serious injury to the person or property of anyone; or

(b) to prevent anything being done that, on reasonable grounds, he believes would, if it were done, be an offence mentioned in paragraph (a). ${ }^{37}$

Furthermore, section 32(1) of the Criminal Code permits a police officer to employ "as much force as the ... officer believes, in good faith and on reasonable grounds, is necessary to suppress a riot, and is not excessive, having regard to the danger to be apprehended from the continuance of the riot." 38 It does not require the person injured by the officer to have unlawfully assaulted the officer before the officer is entitled to use necessary force.

The Criminal Code protects a person who is required or authorized to administer or enforce a law from criminal and civil liability, if the person acts on reasonable grounds and only uses necessary, and not excessive, force in doing so.

In addition to the statutory protections in section 25 for those acting under the authority of law, police officers may rely upon the general statutory defences of self-defence against unprovoked assaults, self-defence in the case of aggression, and justification in using force to prevent an assault. ${ }^{39}$

Considered together, these provisions of the Criminal Code undoubtedly permit the use of the CEW to inflict a non-life-threatening or non-grievous injury for the purposes of making an arrest as long as it is deemed necessary and is based on reasonable grounds. An officer acting within his or her scope of authority, as defined by statute or common law, may use as much force as necessary and be exempted from the traditional criminal law precept that intentional application of force by any means without the other person's consent is unlawful.

If the police conduct at issue falls within the duties of the police, the next step is to determine whether the conduct and use of powers was justified. In $R v \operatorname{Simpson}$, the Court explained that "the justifiability of an officer's conduct depends on a number of factors including the duty being performed, the extent to which some interference with individual liberty is necessitated in order to perform that duty, the importance of the performance of that duty to the public good, the liberty interfered with, and the nature and extent of the interference." 40

While many scenarios involving the use of force invoke powers of arrest under section 495 of the Criminal Code, officers also have common law and provincial powers, for example, to engage in investigative detention including the power to frisk, enter premises without a warrant in certain circumstances, or stop motor vehicles, which bring them into 
conflict with the public. ${ }^{41}$ In the scenario where a person resists a lawful arrest, or interferes with the appropriate use of an officer's common law powers, that individual may be charged with an indictable offence because the officer and others coming to his or her aid are authorized to use as much force as is reasonable and necessary in the circumstances.

Section 25(1) of the Criminal Code makes it clear that the force used to accomplish the lawful purpose must correspond to the act authorized by law, usually an arrest or detention. Where the use of force is justified, a police officer "is not expected to carefully measure the exact amount of force the situation requires." 42 Common law provides further insights into the circumstances and conditions in which the CEW could be employed. The use of the CEW as a means of obtaining compliance when the accused remains uncooperative has been widely recognized in case law.

In $R v$ Eriksson, "[t]he Accused was being uncooperative in response to [Constable] Millar's requests to remove her jewellery. The Accused struck Cst. Millar's hand with her hand in an obvious show of defiance and with sufficient force to cause the Accused's earring to fall to the floor." 43 After an initial verbal warning by an officer that force would be used, further non-compliance of the accused was followed by an application of a taser. At trial, the judge found that the use of the taser was an appropriate elevation in the amount of force needed to gain compliance over the accused, since verbal persuasion and open-hand control was not producing the desired compliance, and such application of force was in conformity with the prevailing RCMP policy regarding the use of force. ${ }^{44}$ A similar conclusion was reached in $R v M L M$, where the Court indicated that the accused's resistance "necessitated the use of the taser." 45

Consistent with the National Use of Force Framework (NUFF), ${ }^{46}$ the taser is a tool available to officers when their presence, communication skills, instructions/commands, or direct physical attempts at control without using a weapon, are not adhered to, are unsuccessful during an incident, or are inappropriate for the type of threat.

A suspect's behaviour during an incident is one of the key components assessed by officers as part of their use of force decision-making. The NUFF categorizes and explains these behaviours:

Co-operative

The subject responds appropriately to the officer's presence, direction and control.

41

The powers and duties of constables at common law were described in $R v$ Waterfield, [1964] 1 QB 164 at 168. See also Knowlton $v R$, [1973] SCR 443 at 446-7l; Dedman, supra note 24 at para 14; $R v$ Godoy, [1999] 1 SCR 311 at para 15; $R$ v Mann, 2004 SCC 52, [2004] 3 SCR 59 at paras 24-26; $R v$ Caslake, [1998] 1 SCR 51 at paras 12-14.

42 Nasogaluak, CA, supra note 31 at para 22. See also $R v$ Mulligan (2000), 142 CCC (3d) 14 (Ont CA) at para 41.

2004 BCPC 34, [2004] BCJ no 336 at para 68 (QL) [Eriksson].

Ibid at paras 69-70. See also $R v$ Knuhtsen, 2009 BCPC 352, 91 MVR (5th) 176.

2006 ABPC 170, 72 WCB (2d) 199 at para 95 [MLM].

Canadian Association of Chiefs of Police (CACP), National Use of Force Framework, (Ottawa: Canadian Association of Chiefs of Police, 2000), online: CACP <http://www.cacp.ca/media/library/ download/266/Useofforcemodel.pdf>. 
Resistant (Passive)

The subject refuses, with little or no physical action, to cooperate with the officer's lawful direction. This can assume the form of a verbal refusal or consciously contrived physical inactivity.

Resistant (Active)

The subject uses non-assaultive physical action to resist, or while resisting an officer's lawful direction. Examples would include pulling away to prevent or escape control, or overt movements such as walking toward, or away from an officer. Running away is another example of active resistance.

Assaultive

The subject attempts to apply, or applies force to any person; attempts or threatens by an act or gesture, to apply force to another person, if he/she has, or causes that other person to believe upon reasonable grounds that he/she has, present ability to effect his/her purpose. Examples include kicking and punching, but may also include aggressive body language that signals the intent to assault.

Grievous Bodily Harm or Death

The subject exhibits actions that the officer reasonably believes are intended to, or likely to cause grievous bodily harm or death to any person. Examples include assaults with a knife stick or firearm, or actions that would result in serious injury to an officer or member of the public. ${ }^{47}$

In practice, the police in Canada have used the CEW when they have been dealing with subjects who engaged in actively resistant or assaultive behaviours, or actions threatening grievous bodily harm or death. That policy was consistent with the Canadian case law which was current at the relevant time.

$R v$ Carson $^{48}$ is illustrative of the type of resistance on the part of a suspect which may necessitate the use of the CEW. Edmonton police officers had confronted the accused at his home and attempted to arrest him on outstanding warrants. Mr. Carson tried to escape into his home and an officer fired taser probes at him when he retreated. The judge found that, since Carson had broken away from the arresting officer's grasp, this behaviour "amounted to more than a passive resistance,” thereby justifying the officer's use of the taser. ${ }^{49}$

Recently, however, considering the circumstances surrounding the high profile Dziekanski case, the appropriateness of such a framework has been questioned. The Braidwood Commission was critical of existing "force-centric" policy and a training paradigm that fostered "poor decision-making," and the "incomplete risk assessment that discounted [the accused's] emotional state.”50

CACP, A National Use of Force Framework (Ottawa: Canadian Association of Chiefs of Police, 2000) at 7-8, online: CACP <http://www.cacp.ca/media/aboutus/policyguidelines/6/Microsoft_Word_textEng-Dec2001.pdf $>$.

$48 \quad 2007$ ABPC 58, 421 AR 139 [Carson].

$49 \quad$ Ibid at para 12.

$50 \quad$ Braidwood Commission Report, Part 2, supra note 7 at 250. 
In 2008 several public agencies recommended that the threshold of a subject's behaviour that must be reached before an officer is justified in deploying a CEW should be raised from “active resistance” to "assaultive." ${ }^{11}$ In June 2008, the Standing Committee on Public Safety and National Security, following a report on RCMP use of the taser, required the RCMP to make a number of improvements to its CEW policies, training practices, and reporting requirements. The first recommendation was to classify the CEW as an impact weapon "so that its use can be authorized only in situations where the subject is displaying assaultive behaviour or posing a threat of death or grievous bodily harm.”52

Although the RCMP has modified and updated its Incident Management/Intervention Model, or (IM/IM), the term "impact weapon" does not appear in the new IM/IM nor does it explicitly limit the use of the $\mathrm{CEW}$ to the situation involving assaultive behaviour or threats of death or grievous bodily harm. ${ }^{53}$

On 30 April 2010, the RCMP amended its CEW operational manual. The updated policy stipulates that " $[\mathrm{t}]$ he CEW must only be used in accordance with CEW training, the principles of the Incident Management/Intervention Model (IM/IM) and when a subject is causing bodily harm, or the member believes on reasonable grounds, that the subject will imminently cause bodily harm as determined by the member's assessment of the totality of the circumstances." 54 This amendment was drafted in response to direct criticism from the Kennedy Commission Report, which required the RCMP to clarify "what the appropriate circumstances for using the CEW are and what threat threshold will be utilized to assess the appropriateness of such use."55 It also mirrors a recommendation from the Braidwood Commission Report. Citing the direct and indirect medical risks associated with the use of CEWs and the importance of adhering to the principle of proportionality embedded in Canadian values, the Braidwood Commission concludes that the existing threshold is set too low. Instead, Commissioner Braidwood proposes a new one: “[T]he subject behaviour threshold should be met when the subject is causing bodily harm or the officer is satisfied, on reasonable grounds, that the subject's behaviour will imminently cause bodily harm."

In the absence of lesser-force options, CEW deployment is permissible in two situations: (1) when the subject has already started and continues causing bodily harm; and (2) when the subject has not yet started to cause bodily harm, but an imminent threat of such harm already

51 See e.g. CPC, RCMP Use of the Conducted Energy Weapon (CEW): Final Report (Ottawa: Canadian Commission for Public Complaints Against the Royal Canadian Mounted Police, 2008) at 11, 49, online: CPC < http://www.cpc-cpp.gc.ca/af-fr/PDF/FinalCEWReport_e.pdf > . See also CPC, RCMP Use of the Conducted Energy Weapon (CEW): Interim Report Including Recommendations for Immediate Implementation (Ottawa: Canadian Commission for Public Complaints Against the Royal Canadian Mounted Police, 2007) at 35 [Interim Report], online: CPC <http://www.cpc-cpp.gc.ca/affr.pdf/InterimTaserReport.pdf>; Alice Almond et al, Report of the Advisory Panel to the Minister of Justice on the Use of the Conducted Energy Device by Law Enforcement Agencies in Nova Scotia (Halifax: Nova Scotia Department of Justice, 2008) at 7, online: Nova Scotia <http://www.gov.ns.ca/ just/global_docs/CED_2_20080630.pdf>; Ombudsman Saskatchewan, My Brother's Keeper: AReview of Electronic Control Devices in Saskatchewan Correctional Centres Housing Male Inmates (Regina: Ombudsman Saskatchewan, 2008) at 17, online: Ombudsman Saskatchewan <http://www.ombudsman. sk.ca/uploads/document/files/my-brothers-keeper-en.pdf>.

Evidence, supra note 35 at 0905.

Ibid.

RCMP, Operational Manual - Conducted Energy Weapon (2010) at 3.1.1, online: RCMP <http:// www.rcmp-grc.gc.ca/ccaps-spcca/cew-ai/operations-17-7-eng.htm> [Manual].

Kennedy Commission Report, supra note 9 at 38.

Braidwood Commission Report, Part 1, supra note 10 at 307. 
exists. In the latter case, the officer's decision to employ the CEW is based on a quasisubjective test: "the officer must personally believe that deployment is necessary (the subjective element) [and] a disinterested third person who is aware of all the circumstances and is acting reasonably would also reach the same conclusion (the objective element)."57

Setting a specific threshold for CEW use in its operational manual is a welcome improvement of the RCMP's CEW policy and a step in the right direction. Yet, the updated definition is still broad enough to allow CEW use in the absence of actual bodily harm and/or a threat of death or grievous bodily harm. The RCMP's position on this issue has not changed since it was last articulated by Commissioner William Elliott in February 2009:

In situations of death or grievous bodily harm, we believe an appropriate response ... is lethal force.... We do not train our officers to respond with like force with respect to the threat they are facing. We teach them ... to respond with greater force. So if, with respect to them or another individual, there is a threat of death or grievous bodily harm, we authorize and instruct our officers to use lethal force. ${ }^{58}$

Canadian courts, however, have expressed concerns about the deployment of the CEW under such circumstances. Consider, for instance, $R v$ Ashe:

\begin{abstract}
On all the evidence in this case, ... I believe that Constable Gravelle and Sergeant Campbell could have effected the arrest of Ashe by less intrusive means. These "less intrusive means" have been taught to all police officers during their training. Although not in this case, they may involve risk to the officers. I have a concern that deployment of the Taser is viewed by some officers as an "easier" way to effect an arrest rather than the use of options of a "less intrusive manner", and that Taser use is resorted to too frequently where the circumstances governing its use are not present. ${ }^{59}$
\end{abstract}

In $R v$ Dianocky, the Court emphasized that, although "no one can measure to a nicety how police can respond to physical force or anyone can respond," the police "must consider" that "[p]utting 50,000 volts of electricity into a person's body can be injurious and should not be used as a first line of control when other means are available, and they are not facing deadly force." ${ }^{60}$ It was pointed out that, in the circumstances under consideration: "[t]wo officers should have been able to physically subdue the accused ... Tasers should not be used just because it is easier or less physically exerting." 61 Therefore, a threat of causing bodily harm alone (unlike a threat of grievous bodily harm or death) does not constitute sufficient grounds per se for CEW use.

The Braidwood Commission has reached a similar conclusion and reiterated that meeting the threshold does not in itself automatically justify deploying a CEW. It recommends that an officer should be prohibited from deploying a CEW unless he or she "is satisfied, on reasonable grounds, that; no lesser force option has been, or will be, effective in eliminating 
the risk of bodily harm; and de-escalation and/or crisis intervention techniques have not been or will not be effective in eliminating the risk of bodily harm." ${ }^{62}$

This recommendation is consistent with a general view that the taser "should not be viewed as a panacea for any form of non-cooperative or resistant behaviour" 63 but rather as "a weapon of last resort before the use of a firearm."64

Consider, for example, $R v$ Paton. ${ }^{65}$ In this case, an officer testified that he suspected alcohol consumption and told the accused to exit the vehicle for roadside tests. The accused asked to speak to his lawyer, said he feared for his life, and did not believe the officer was indeed a police officer. ${ }^{66}$ The officer testified that he had a strong suspicion that the accused had alcohol in his body and ordered him to provide a sample of breath for analysis by means of an approved screening device. Mr. Paton refused, stating that "he would incriminate himself" and that "he was confused." 67 The officer then used a taser to stun the accused and removed him from the vehicle to compel him to provide sample. The Court noted that the accused did not pose a threat to the officer's safety. The judge was concerned that the police officer appeared to believe that he had a right to order the accused around and to threaten him with the application of the taser for failure to promptly obey the officer's demands. ${ }^{68}$

The authorized use of a CEW still requires the exercise of the utmost care possible under the circumstances. Canadian courts in multiple cases have reiterated the importance of issuing a verbal warning before applying the CEW. ${ }^{69}$ The recently updated RCMP policy with respect to CEW use, however, stops short of requiring its members to issue a verbal warning before any instance of CEW deployment. Instead, it limits this requirement to situations where it is considered "tactically feasible."70

Additionally, police CEW policies prohibit applying the taser at a suspect's head, as such conduct may increase the likelihood of death or grievous injury. ${ }^{71}$ The Braidwood Commission, based on its thorough examination of medical risks associated with the use of CEWs, suggested two additional precautionary measures: requiring police officers who carry CEWs to have automated external defibrillators and paramedic assistance in every medically high-risk situation, which may include:

deployment in probe mode across the subject's chest;

Braidwood Commission Report, Part 1, supra note 10 at 19.

$R v$ Hannibal, 2003 BCPC 504, [2003] BCJ no 3119 (QL) at para 158.

$R v$ Betty, 2008 ONCJ 247, 77 WCB (2d) 364 at para 79 [Betty]

2006 SKPC 7, 309 Sask R 1 [Paton].

Ibid at para 5.

Ibid.

Ibid at para 22.

See e.g. Betty, supra note 64 at para 85. See also $R$ v Sparks, 2004 CarswellOnt 5917 (Sup Ct J) [Sparks].

Manual, supra note 54 at section 3.1.4.

See e.g. James M Cronin \& Joshua A Ederheimer, Conducted Energy Devices: Development of Standards for Consistency and Guidance (Washington: US Department of Justice Office of Community Oriented Policing Services \& Police Executive Research Forum, 2006); TASER International, Inc, News Release, “Training Bulletin 15.0: Medical Research Update and Revised Warnings” (12 October 2009), online: FBI National Academy Associates <http://www.spokanecounty.org/data/countysheriff/pdf/ tasers/TASER\%20Training\%20Bulletin\%2015_0\%20Medical\%20Research\%20with\%20Product\%20 Warnings_2.pdf $>$. 
- $\quad$ deployment in probe mode for longer than five seconds;

- $\quad$ deployment in any mode against:

- an emotionally disturbed person;

- an elderly person;

- a person who the officer has reason to believe is pregnant; or

- a person who the officer has reason to believe has a medical condition that may be worsened because of the deployment (e.g., heart disease, implanted pacemaker or defibrillator, etc.). ${ }^{72}$

The taser can be applied repeatedly if such use is necessary in the presence of continuous physical aggressive behaviour by the accused. For example, in Leeson, Sergeant Blakeley used her taser several times during the investigation, detention, and ultimate arrest of Mr. Leeson when it became apparent that her efforts to de-escalate Leeson's behaviour and to talk with him were fruitless. After assessing the evidence, the judge found that the repeated "use of the taser ... was objectively reasonable in all of the circumstances, given ... Leeson's continuing behaviour and the fact that he was not under the full control of the police."73

However, repeated use of the CEW in the absence of continuous active resistance is considered excessive. For example, in $R v$ Fryingpan, ${ }^{74}$ police officers deployed a taser several times during - and subsequent to - ejecting Mr. Fryingpan from an unlocked and inoperable car where he was sitting and drinking with a group of friends. The Court found this treatment to be excessive in the circumstances, since the situation was clearly under control and the accused did not pose a great threat of harm to the investigating officers. ${ }^{75}$

In $R v$ Merrick, ${ }^{76}$ two police officers had difficulty apprehending the accused in his own house. One of the officers tasered Mr. Merrick while he was in the stairwell. The accused fell and five seconds later was tasered again, while lying on the ground. The fact that the accused man was on the ground for five seconds before being tasered demonstrated that he "was not acting in any fashion which would have warranted that second act." ${ }^{\text {"77 }}$ Although the officer claimed that the accused had been "actively resisting by telling [the officers] to get out of his house,"78 Judge Andre rejected this assertion and found that the second application of the taser constituted "gratuitous and excessive force."79

In a similar vein, the Braidwood Commission Report, Part 1, points to the increasing number of medical risks associated with multiple deployments of CEWs and calls for a revised policy permitting subsequent taser discharges (beyond the initial five-second

Braidwood Commission Report, Part 1, supra note 10 at 315-16.

Supra note 25 at para 81 .

2005 ABPC 28, 373 AR 187 [Fryingpan].

Ibid at para 72 .

2007 ONCJ 260, 74 WCB (2d) 330 [Merrick].

Ibid at para 55.

Ibid at para 53.

Ibid at para 55. 
application) only if an "officer is satisfied, on reasonable grounds, that: the five-second discharge was not effective in eliminating the risk of bodily harm; and a further discharge will be effective in eliminating the risk of bodily harm." ${ }^{80}$ In its second report, the Commission concluded that the weapon's failure to immobilize an accused cannot, per se, justify a second deployment of the weapon: "It is ridiculous to suggest that when a subject is lying on the ground, kicking and screaming in pain, an officer is justified in deploying a conducted energy weapon a second time, especially when the officer knows that there are risks associated with multiple deployments.”81

The Standing Committee on Public Safety and National Security has requested similar changes in the RCMP's policy and has called for clear guidelines for CEW use and for the imposition of restrictions on multiple discharges of the CEW. So far, it has not been fully implemented. Although the updated RCMP policy does include a warning that "[m]ultiple deployment or continuous cycling of the CEW may be hazardous to a subject," it permits repeated cycling of the CEW if "situational factors dictate otherwise." ${ }^{2}$ Yet subjecting multiple deployments to a high level of scrutiny would be consistent with the existing case law that stipulates that the CEW can only be used in the presence of a threat to an officer's safety. It means that such force cannot be justified once the threat of causing bodily harm has abated; hence, the situation needs to be continuously reassessed before any additional discharge can be applied. This rule was first confirmed in $R v$ Walcott, ${ }^{83}$ where the taser was applied through five cycles against the accused, who "was lying face down on the floor, handcuffed, and was fully restrained and compliant." 84 After considering the evidence revealed upon examination of the taser's data chips, the judge found that the discharge of the taser after a person has been restrained and controlled would have had no other purpose than to punish that individual, which would constitute "cruel and unusual treatment" in violation of section 12 of the Canadian Charter of Rights and Freedoms. ${ }^{85}$

Similarly, in Sparks, a taser was used on the accused after he had ceased to resist. The accused initially resisted the extraction from his cell and was subsequently tasered. According to the current existing legal framework, the first application of the taser was not in violation of the accused's Charter rights. ${ }^{86}$ However, the second application of the taser, when Mr. Sparks was escorted down a hall, was found to be "gratuitous," an "excessive use of force," amounting to "extrajudicial punishment” violating the section 12 prohibition on cruel and unusual treatment or punishment. ${ }^{87}$

Supra note 10 at 314 .

Braidwood Commission Report, Part 2, supra note 7 at 255.

Manual, supra note 54, at 3.1.5; Interim Report, supra note 51, Appendix C, 3.1.3.

(2008), 57 CR (6th) 223 [Walcott].

Ibid at para 107.

Part 1 of the Constitution Act, 1982, being Schedule B to the Canada Act 1982 (UK), 1982, c 11, s 12 [Charter].

Given the current elevated standard, the first application of the taser under similar circumstances would be considered excessive.

Sparks, supra note 69 at paras 51-52. 


\section{EXCESSIVE USE OF THE CONDUCTED ENERGY WEAPON AND Legal Mechanisms of Police Accountability}

This section focuses on the legal mechanisms for achieving police accountability that exist or should be put in place to limit unauthorized, excessive use of the CEW. The use of the CEW without acceptable legal justification may result in procedural, criminal, civil, and administrative consequences. Police officers are prohibited from using force, including the CEW that violates the provisions of the Charter and the Criminal Code. Unwarranted use of the taser may constitute a violation of sections 7 and 12 of the Charter that guarantee everyone "the right to life, liberty and security of the person" and "the right not to be subjected to any cruel and unusual treatment or punishment.",88

An accused whose constitutional rights have been violated can resort to section 24(1) of the Charter: "Anyone whose rights and freedoms, as guaranteed by this Charter, have been infringed or denied may apply to a court of competent jurisdiction to obtain such remedy as the court considers appropriate and just in the circumstances." ${ }^{\text {,99 }}$

Canadian courts treat very seriously the excessive use of force to apprehend a suspect. In most cases, it has been held that excessive use of the CEW amounts to a breach of the accused's Charter rights and should mandate a stay of criminal proceedings against those individuals who have been the victims of excessive force. The first successful use of the Charter to obtain a judicial stay of proceedings within the context of police taser use appears to be Fryingpan, in which a youth had been subjected to multiple applications of the taser that were found to constitute an excessive use of force. The police misconduct was viewed as being representative of "the clearest of cases" that involved prejudice to the accused's right to a fair trial and/or the right to make full answer and defence, thereby warranting the remedy of a stay of proceedings. ${ }^{90}$

In cases where the extent of violation is not extreme as to justify a stay of proceedings, a reduction of sentence of the accused who has been subjected to taser treatment may be in order. ${ }^{91}$ In $R v$ Delong, ${ }^{92}$ a new trial was ordered because the issue of excessive force involving the use of the taser had not been considered. In Paton, the Court granted the accused's request to exclude evidence based on the fact that his right not to be arbitrarily detained or imprisoned guaranteed under section 9 of the Charter had been violated. ${ }^{93}$ In this case, the taser was used to facilitate the police in their arbitrary detention of Paton. As Judge Matsalla stated: "[ $\mathrm{t}]$ he detention became arbitrary shortly after the stop but the actions of the

Supra note 85 , ss 7, 12.

\section{Ibid, s 24(1).}

Supra note 74 at para 74. See also Walcott, supra note 83; Paton, supra note 65; Betty, supra note 64; Eriksson, supra note 43; MLM, supra note 45; Merrick, supra note 76. For a detailed discussion on the judicial stay of proceedings concept in cases involving use of tasers by law enforcement officers see David MacAlister, "Reviewing Police Use of Tasers: Recent Developments Include Application of the Abuse of Process Doctrine" (2008) 57 CR (6th) 263.

See e.g. Carson, supra note 45; Sparks, supra note 66.

2008 BCSC 923, [2008] BCJ no 1320 (QL).

Paton, supra note 65 at para 23. In Paton, the admissibility of evidence obtained by a Charter breach violation was decided based on the Collins test, $R v$. Collins, [1987] 1 SCR 265, which has recently been replaced by a new test articulated in $R v$ Grant, 2009 SCC 32, [2009] 2 SCR 353. 
police officer became more egregious due to the unjustified application of force by way of the Taser. I have no doubt that the breach in this case was very serious." 94

These cases demonstrate that courts are willing to consider alternative remedies to a stay of proceedings. Another alternative remedy available under section 24 of the Charter, rarely ordered by criminal courts, is an award of costs in favour of the accused. ${ }^{95}$ In $R v$ Leduc, ${ }^{96}$ it was held that, although costs may be awarded under section 24(1) of the Charter, they should be restricted to cases where there are "circumstances of a marked and unacceptable departure from the reasonable standards expected of the prosecution." ${ }^{\text {"97 }}$ Indeed, there are a number of cases where courts have found it appropriate to award both a judicial stay and costs. $^{98}$

\title{
In Agat, Judge Fradsham stated:
}

\begin{abstract}
In my view, there is nothing which prohibits the combination of a monetary remedy and a judicial stay of Proceedings. Without doubt, the entry of a judicial stay is an extreme measure to be resorted to only when no other remedy or remedies will adequate address the prejudice suffered by the accused as a result of the Charter breach. However, that does not mean that the judicial stay alone will address all aspects of the prejudice suffered by the accused. The judicial stay may be a necessary part of effecting a complete remedy, but likewise an economic component to the remedy provided may also be necessary to achieve a complete remedy. $^{99}$
\end{abstract}

Where the stay of proceedings provides a remedy for an unfair trial, the award of costs addresses all other consequences arising as a result of a Charter right violation.

The courts must be vigilant in adequately protecting the public interest in ensuring fair trials involving all accused, guilty or innocent. In cases where a fair trial has not occurred owing to "a marked and unacceptable departure from the reasonable standards expected of the prosecution,” remedial measures in the form of costs are appropriate, even when a stay of proceedings has been entered. ${ }^{100}$

In 974649 Ontario Inc, the Court stated:

To the extent that it is difficult or impossible to obtain remedies for Charter breaches, the Charter ceases to be an effective instrument for maintaining the rights of Canadians.

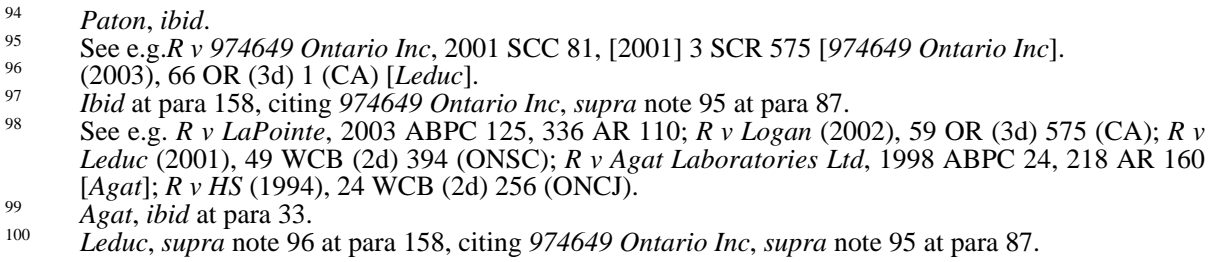


[Section] 24(1) must be interpreted in a manner that provides a full, effective and meaningful remedy for Charter violations.

Section 24(1)'s interpretation necessarily resonates across all Charter rights, since a right, no matter how expansive in theory, is only as meaningful as the remedy provided for its breach. ${ }^{101}$

An accused should be encouraged to seek a remedy for a Charter breach, and the costs involved in pursuing that remedy should not preclude him or her from seeking such remedy. The reluctance of the courts to consider awarding costs along with other remedies would inevitably result in a diminution of the value of an accused's Charter rights.

Another potential remedy that may be granted under section 24(1) for a violation of a constitutional right by the police is an award of damages. The Supreme Court of Canada has recognized that, while damages do not constitute the primary remedy for violation of constitutional rights under this provision, they may nevertheless constitute an "appropriate and just remedy” in special circumstances. ${ }^{102}$

In Vancouver (City of) $v$ Ward, Chief Justice McLachlin articulated the underlying rationale for awarding damages under section 24(1):

[D]amages under s. 24(1) of the Charter are a unique public law remedy, which may serve the objectives of:

(1) compensating the claimant for loss and suffering caused by the breach;

(2) vindicating the right by emphasizing its importance and the gravity of the breach; and

(3) deterring state agents from committing future breaches. Achieving one or more of these objects is the first requirement for "appropriate and just” damages under s. 24(1) of the Charter. ${ }^{103}$

Indeed, among other cases, damages have been awarded pursuant to section 24(1) of the Charter in cases where police officers have violated such basic rights as the right against abitrary detention (section 9), ${ }^{104}$ the right to counsel (section 10), ${ }^{105}$ the right not to be subjected to cruel and unusual treatment or punishment (section 12), ${ }^{106}$ the right to be secured

Supra note 95 at paras 1, 19, 20 [emphasis in original].

RJR-MacDonald Inc v Canada (AG), [1994] 1 SCR 311 at 34-42. See also Hawley v Bapoo (2005), 76 OR (3d) 649 (Sup Ct) at para 185 [footnote omitted], where Justice Ducharme summarized the relevant principles that should be applied when a constitutional tort has been committed: "First, there is no question that one can bring an action for constitutional torts.... Second, such actions can be brought against all government actors, i.e., either governments or those discharging their powers. Third, while damages are not the primary remedy in [Charter] cases, where a constitutional violation is made out damages can be awarded under s. 24(1) where "appropriate and just in the circumstances." However, on appeal, the Ontario Court of Appeal ruled that the plaintiff must prove "mala fides or wilfulness as a prerequisite for an award of damages for a constitutional tort under the Charter" and set aside the award of damages made by the trial judge against two police officers: Hawley v Bapoo, 2007 ONCA 503, 227 OAC 81 at para 9 [Hawley].

2010 SCC 27, [2010] 2 SCR 28 at para 31 [Ward].

See e.g. Blouin $v$ Canada (1991), 51 FTR 194 (TD).

See e.g. Crossman v R, [1984] 1 FC 681 (TD); Lord v Allison (1986), 17 WCB 16 (BCSC) [Allison]. See e.g. Allison, ibid. 
from unreasonable search and seizure (section 8), ${ }^{107}$ and the right not to be deprived of the security of the person in a manner that is contrary to the fundamental principles of justice (section 7). ${ }^{108}$

In Ward, the Supreme Court of Canada set out the steps that courts should follow when determining whether or not damages should be awarded under section 24(1). Chief Justice McLachlin stated that the first step must be to establish that a breach of the Charter has occurred. The second step is to address the "functional justification of damages:"

A functional approach to damages finds damages to be appropriate and just to the extent that they serve a useful function or purpose.

For damages to be awarded, they must further the general objects of the Charter. This reflects itself in three interrelated functions that damages may serve. The function of compensation, usually the most prominent function, recognizes that breach of an individual's Charter rights may cause personal loss which should be remedied. The function of vindication recognizes that Charter rights must be maintained, and cannot be allowed to be whittled away by attrition. Finally, the function of deterrence recognizes that damages may serve to deter future breaches by state actors. ${ }^{109}$

The third step arises after the claimant has established that an award of damages is "functionally required to fulfill one or more of the objects of compensation, vindication of the right, or deterrence of future Charter breaches." 110 At this point, the state has the opportunity to convince the court that there are "countervailing considerations" that "render s. 24(1) damages inappropriate or unjust.”111 Two important “countervailing considerations” are "the existence of alternative remedies and concerns for good governance.",

The fourth, and final, step which the court must take is to assess the quantum of damages. In this respect, Chief Justice McLachlin opined that:

The watchword of s. 24(1) is that the remedy must be "appropriate and just". This applies to the amount, or quantum, of damages awarded as much as to the initial question of whether damages are a proper remedy.

To sum up, the amount of damages must reflect what is required to functionally serve the objects of compensation, vindication of the right and deterrence of future breaches, insofar as they are engaged in a

Chrispen v Prince Albert (City of) Police Department (1997), 148 DLR (4th) 720 (Sask QB); Ward, supra note 103, where a $\$ 5,000$ award for an illegal strip search was upheld by the Supreme Court of Canada.

See e.g. Hawley, supra note 102; Bevis v Burns, 2006 NSCA 56, 244 NSR (2d) 211.

Supra note 103 at paras 24-25 [emphasis omitted].

Ibid at para 32.

Ibid at para 33.

Ibid. 
particular case, having regard to the impact of the breach on the claimant and the seriousness of the state conduct. The award must be appropriate and just from the perspective of the claimant and the state. ${ }^{113}$

Canadian criminal law provides for yet another mechanism to keep the police accountable for inappropriate use of CEWs. A deployment of the taser in an attempt to arrest without legal authority constitutes an unlawful assault because the officer would not be in the lawful execution of his duties. ${ }^{114}$ While common law does afford police officers greater powers than those of private citizens by permitting detention and non-consensual touching, "no authority outside of the Criminal Code [protects them] from penal liability once they step outside of" the parameters of their powers, as they are articulated in section 25 of the Criminal Code. ${ }^{115}$

Section 26 of the Criminal Code provides that those individuals, such as police officers, who are authorized to use force under section 25, are criminally responsible for any excessive use of force: "Every one who is authorized by law to use force is criminally responsible for any excess thereof according to the nature and quality of the act that constitutes the excess." 116

In the context of taser use, the case of $R v$ Shott $^{117}$ is illustrative. The officer was investigating an allegation of obtaining taxi services by fraud, through failure to pay the fare. Upon a brief on-scene investigation, the officer decided to arrest the alleged suspect, $\mathrm{Mr}$. Brown, and deployed the taser when he resisted by retreating from the officer. Subsequently, Brown was released when it had been determined that insufficient grounds existed to support a charge. The lack of reasonable grounds for suspicion necessary to exercise the power of arrest led to the judge's finding that there was no justification for the application of force in these circumstances and the accused officer's ultimate conviction.

Another more recent case is Parsons v Niagara (Regional Municipality of) Police Services Board. ${ }^{118}$ In this case the male plaintiff, Mr. Parsons, and his fiancée drove by police officers at the scene on the side of a highway, and he shouted offensive comments at a police officer believed to be known to him. Police officers stopped the plaintiff's vehicle, used force against Parsons, and tasered him. Officer Tallevi arrested and imprisoned Parsons; however, the charges were later dropped. The plaintiffs brought an action against the police officers for negligence, false arrest, assault, malicious prosecution, and breaches of their rights under the Charter. The officers were found to be not credible, and Officer Tallevi was charged for having falsely arrested Parsons. Although Parsons' injuries from the taser application were not serious, the assault was deemed "particularly offensive and egregious ... involving at least one taser application to Mr. Parsons' genitals and many other very painful electrical shocks, some of which were applied while he was handcuffed." ${ }^{119}$ Parsons was awarded $\$ 30,000$ in general damages.

\footnotetext{
$113 \quad$ Ibid at paras 46, 57.

$114 \quad$ See e.g. $R v$ Webers (1994), 95 CCC (3d) 334 at 344 (Ont Ct J (Gen Div)); $R v$ Plummer (2006), 83 OR (3d) 528 (CA) at paras 48-49. See also $R v$ Delong (1989), 31 OAC 339 at para 41.

115 Ian D Scott, “Legal Framework of Use of Force by Police in Ontario” (2008) 53:3 Crim LQ 331 at 341. See especially $R v$ Campbell, [1999] 1 SCR 565.

Supra note 27, s 26.

2006 ABPC 265, 410 AR 93 [Shott]. (2009), 193 CRR (2d) 330 [Parsons]. Ibid at para 168 .
} 
It should be noted, however, that the decisions reached in Shott and in Parsons are likely to be exceptional rather than routine, since Canadian courts are generally quite reluctant to convict officers charged with assault in similar circumstances. The remainder of the cases that involved charges of assault with the taser as a weapon resulted in the acquittal of the accused police officers. In $R v$ Galloway, ${ }^{120} R v$ Hope,${ }^{121} R v$ St Arnand, ${ }^{122}$ and $R v$ Huynh, ${ }^{123}$ the Courts found the application of the taser to have been justifiable in the circumstances. Section 25(2) protects the police and those aiding them, providing they act in good faith in executing a legal process, even where that process is subsequently found to be defective. The courts often generously construe the officer's subjectively held belief in a set of circumstances leading to an arrest, even if it is proven to be ultimately incorrect owing to the often chaotic and dangerous circumstances in which arrests take place. Indeed, in $R v$ Cornell, the Supreme Court of Canada made this point very succinctly:

[T] he police must be allowed a certain amount of latitude in the manner in which they decide to enter premises. They cannot be expected to measure in advance with nuanced precision the amount of force the situation will require ... It is often said of security measures that, if something happens, the measures were inadequate but that if nothing happens, they were excessive. These sorts of after-the-fact assessments are unfair and inappropriate when applied to situations like this where the officers must exercise discretion and judgment in difficult and fluid circumstances. The role of the reviewing court in assessing the manner in which a search has been conducted is to appropriately balance the rights of suspects with the requirements of safe and effective law enforcement, not to become a Monday morning quarterback. ${ }^{124}$

Similar reasoning was offered in the more recent case of $R v$ Brown. ${ }^{125}$ Thus, as long as the officer has a reasonable basis for his belief that the arrest or detention was appropriate, the ensuing force used will be deemed necessary.

Civil litigation involving CEW use in a police setting presents another interesting venue to examine. An emerging trend of growing civil litigation against the police is often attributed to higher standards of accountability for public institutions and an increasing willingness on the part of members of the public to file lawsuits. Society as a whole expects law enforcement to be more accountable and legal changes have broadened the definition of police negligence. TASER International, Inc has been named in a number of product liability lawsuits arising from law enforcement use of the taser; however, the vast majority of them took place in the US. In Canada, the Police Acts of most provinces exclude individual liability for any tort committed by an officer if she or he acts in good faith and within the scope of her or his duties. In British Columbia, for example, section 21(2) of the Police Act maintains:

21(2) No action for damages lies against a police officer or any other person appointed under this Act for anything said or done or omitted to be said or done by him or her in the performance or intended performance of his or her duty or in the exercise of his or her power or for any alleged neglect or

\footnotetext{
1202006 NSPC 12, 69 WCB (2d) 735.

1212007 NSCA 103, 259 NSR (2d) 99.

$122 \quad 2006$ BCPC 508, [2006] BCJ no 3059 (QL).

123 [2005] AJ no $1924(\mathrm{QL})$.

1242010 SCC 31, [2010] 2 SCR 142 at para 24. See also $R v$ Asante-Mensah, 2003 SCC 38, [2003] 2 SCR 3 at para 73; Walcott supra note 83 at para. 23.

1252009 ONCJ 425, [2009] OJ no 3820 (QL) at para 164.
} 
default in the performance or intended performance of his or her duty or exercise of his or her power. $^{126}$

Municipalities and police boards, however, are not absolved of the liability for torts committed by its police officers. For example, section 20 of the BC Police Act sets out the liability of a city and the police board for the torts of its police officers as follows:

20(1) Subject to an agreement under section 18(1) or 23(2),

(a) a municipality is jointly and severally liable for a tort that is committed by any of its municipal constables, special municipal constables, designated constables, enforcement officers, bylaw enforcement officers or employees of its municipal police board, if any, if the tort is committed in the performance of that person's duties, and

(2) If it is alleged or established that any municipal constable, special municipal constable, designated constable, enforcement officer, bylaw enforcement officer or employee referred to in subsection (1) has committed a tort in the performance of his or her duties, the respective board and any members of that board are not liable for the claim. ${ }^{127}$

Further, section 21(4) of the BC Police Act confirms that a city is vicariously liable for torts committed by police officers "or any other person referred to" in section 21(2). ${ }^{128}$ Similar statutory schemes, outlining municipal and boards' liability for the torts of their officers, exist in other provinces and territories across Canada. Punitive damages may be imposed vicariously or against an employer "if a managerial agent of the employer has acted recklessly in the engaging or the retaining of an employee with the resultant foreseeable danger of harm of the type which occurred here." 129

Under the applicable statutory provisions, municipalities can be held "jointly and severally liable for the torts of [its] police officers." ${ }^{130}$ In limited circumstances, a municipal police board may potentially be held liable for the actions of police officers (for example, by setting policies which are considered to infringe the rights of suspects ${ }^{131}$ or negligently providing equipment to its officers). ${ }^{132}$

In 2007, in Hill v Hamilton-Wentworth Regional Police Services Board, ${ }^{133}$ the Supreme Court of Canada ruled that police in Canada are not immune from civil liability for negligence in their investigations and recognized the tort of negligent investigation. This decision has opened the door to successful civil claims against police officers, whose conduct

Police Act, RSBC 1996, c 367, s 21(2) [BC Police Act].

Ibid, s 20.

Ibid, s 21.

$R(G B) v$ Hollett (1996), 154 NSR (2d) 161 (CA) at para 250.

See e.g. BC Police Act, supra note 126; Ribeiro $v$ Vancouver (City of), 2005 BCSC 828, 139 ACWS

(3d) 845 at para 26 [Ribeiro].

$R v$ Schedel, 2003 BCCA 364, 12 CR (6th) 207 at para 100; Ribeiro, ibid.

Bagnell v Taser International Inc, 2008 BCCA 171, [2008] 6 WWR 585 [Bagnell].

2007 SCC 41, [2007] 3 SCR 129. 
is not consistent with the standard of a reasonable police officer acting in similar circumstances.

So far, in Canada, police use of the taser has been at the centre of civil litigation only once — in Bagnell. The plaintiffs alleged that the Vancouver Police Board was negligent in purchasing and supplying its police officers with tasers and by failing to ensure the weapons were in fact a non-lethal means of intervention. An individual, Mr. Bagnell, died in police custody after he was tasered during the police operation to evacuate him from a hotel which was on fire. His relatives started an action, brought under the British Columbia Family Compensation Act, ${ }^{134}$ claiming that he "died as a result of the use of a taser used by police officers." 135 The Board applied to have the claim against it struck out on the ground that it disclosed "no reasonable claim," as "no private law duty of care [was] owed" to the plaintiffs. ${ }^{136}$ The appeal by the Board was dismissed. An appellate judge found that, although in most instances no private law duty of care was owed by the Board (since the Board's primary role is to provide governance and establish general policies for the police department), section 26(3)(b) of the BC Police Act appears to confer an operational duty on the Board and could "support the necessary relationship of proximity" between plaintiffs and the Board so as to give rise to a prima facie duty of care. ${ }^{137}$ Thus, the Vancouver Police Board may owe a private law duty of care in connection with its supply of tasers to police officers without ensuring that such devices were independently tested and properly maintained.

The civil courts represent, of course, only one of many mechanisms by means of which police activity may be monitored. Other established and effective methods also exist to regulate police behaviour. Some of these methods involve the intervention of the judiciary in different forums and others use quasi-judicial administrative boards and tribunals. The internal police discipline and public complaint processes play prominent roles in regulating police conduct and are valid venues to hold police accountable for any misuse of CEWs.

Public inquiries provide another important mechanism of police accountability. A public inquiry is an official review of important public events or issues ordered by the government to establish the facts and causes of an event or issue, and then to make recommendations. All levels of government (federal, provincial, and territorial) have the power to call public inquiries. Even though they do not exercise judicial functions, public inquiries enjoy many investigatory powers for the purpose of pursuing their primary goal of fact-finding. These include the power to compel witnesses and evidence, and to make findings of misconduct. The public nature of an inquiry has a profound impact on policy development as well as important implications for individuals, institutions, and corporations who are involved in the delivery of public services or other matters of "public concern."

In the context of the CEW, notably, two public inquiries conducted by the Braidwood Commission have had a profound effect on CEW policies in Canada. The Commission was

RSBC 1996, с 126.

Supra note 132 at para 2.

Ibid at para 4.

Ibid at para 29. 
established in February 2008 under the Public Inquiry Act ${ }^{138}$ "to inquire into and report on the death of Mr. Dziekanski” and "to inquire into and report on the use of conducted energy weapons by constables, sheriffs, and authorized persons in British Columbia." ${ }^{139}$ Although the Commission did not have the powers to make findings of criminal or civil liability, it did go far beyond a mere recitation of the facts and resulted in a thorough analysis of police “officers' actions in the context of the factual circumstances they faced, the training they had received, and the RCMP's policies under which they operated." 140

Finally, recent trends towards increased public oversight of the police have manifested themselves, in one jurisdiction, in the creation of an independent public agency that directly investigates suspected criminal conduct by police. Part VII of the Ontario Police Services Act created the "Special Investigations Unit” (SIU), a public agency charged with investigating "circumstances of serious injuries and deaths that may have resulted from criminal offences committed by police officers." ${ }^{\text {"41 }}$ Police officers are required by the same enabling provision to "co-operate fully" with the SIU to ensure a truly impartial investigation free of any potential conflict of interest. ${ }^{142}$ Similar mechanisms of increased accountability have been established or recommended in other provinces. In the context of taser use, the Braidwood Commission recommended the creation of a civilian-based Independent Investigation Office (IIO) with a wide mandate to conduct an external investigation of all police-related incidents occurring throughout British Columbia. ${ }^{143}$

“[P]olice-related incidents” include, but should not necessarily be limited to, incidents: in which a person dies or suffers serious harm:

i. while in the custody or care of a municipal police officer or RCMP officer, or

ii. the death or serious harm could be seen to be the result of the conduct of any municipal police officer or RCMP officer, or

which involve possible contravention, by a municipal police officer or RCMP officer, of:

i. any provision of the Criminal Code, or

ii. any other federal or provincial statute that, if the incident were investigated by a police officer, might in the minds of reasonable, informed members of the public undermine confidence in the police. ${ }^{144}$

SBC 2007, с 9.

Braidwood Commission Report, Part 2, supra note 7 at 31.

Ibid at 247.

Supra note 29, s 113(5).

Ibid, s 113(10).

Braidwood Commission Report, Part 2, supra note 7 at 422.

Ibid. 
To ensure the impartiality of the new agency, it will be accountable to the Ministry of the Attorney General, "led by a director who is neither a current nor former police officer, appointed by Order-in-Council for a fixed, renewable term of five or six years” ${ }^{\text {"145 }}$ and eventually staffed by persons with no prior police service record. On 17 May 2011, the Government of British Columbia announced the creation of an independent Investigations Office, which will operate in accordance with the recommendations of the Braidwood Report. $^{146}$

\section{Conclusion}

The CEW as a measure to obtain compliance when the accused remains uncooperative has been widely recognized in case law. This could be an effective tool in situations when police officers' presence, communication skills, instructions/commands, or direct physical attempts at control without using a weapon are not adhered to, are unsuccessful during an incident, or are deemed to be inappropriate for the type of threat involved.

Until recently, in law enforcement practice in Canada, tasers have been used when dealing with subjects who demonstrated active resistance or assaultive conduct. The articulation of the risks associated with the use of the CEW, the existing framework of policies related to police training practices, the use of tasers in apprehending suspects, and the subsequent reporting of taser deployments all require revision.

First, the revised policies should include provision for an elevated threshold of a subject's behaviour which must be reached before an officer is justified in deploying a CEW. The taser should be explicitly classified as an impact weapon, the use of which is authorized only in situations involving the threat of grievous bodily harm or death. Although the RCMP has recently updated its CEW operational manual, the new criteria is still broad enough to allow CEW use in the absence of actual bodily harm and/or a threat of death or grievous bodily harm. Despite being a step in the right direction, further improvements of the RCMP's CEW policies are necessary to make its practices more consistent with the principle of proportionality that is embedded in Canadian values and with the respect for a person's rights to life, security, and humane treatment that is guaranteed under the Charter.

Second, even if the subject's behavioural threshold is met, CEW deployment is permissible only in the absence of other less forceful options. The revised CEW use-of-force policies should explicitly prohibit police officers from deploying a taser unless they are "satisfied, on reasonable grounds, that ... no lesser force option has been, or will be, effective in eliminating the risk of bodily harm; and de-escalation and/or crisis intervention techniques have not been or will not be effective in eliminating the risk of bodily harm.”147 This recommendation is not only based on conclusions reached by both the Braidwood and

See British Columbia, Ministry of Public Safety and Solicitor General, News Release, 2011PREM0052000555, "Civilian office to investigate serious police incidents" (17 May 2011), online: British Columbia Ministry of Public Safety and Solicitor General < http://www2.news.gov.bc.ca/news releases_2009-2013/2011PREM0052-000555.htm>. 
Kennedy Commissions, it also has a solid foundation in the common law with its prevailing view of the taser as "a weapon of last resort before the use of a firearm."

Third, the authorized use of the CEW should be subject to a set of further restrictions, which together will ensure the exercise of the utmost care possible under the circumstances. These restrictions include issuing verbal warnings before any instance of CEW deployment, prohibition of unwarranted multiple deployments, and precautionary measures when tasers are deployed in medically high-risk situations. ${ }^{149}$

Multiple deployments of the CEW are warranted only in the presence of continuous physical aggressive behaviour by the accused and if an officer is satisfied on reasonable grounds that a further application of the taser "will be effective in eliminating the risk of bodily harm.”150

Finally, since the use of the CEW without acceptable legal justification may result in procedural, criminal, civil, and administrative consequences, adequate and reliable information about them should become part of police training on the use of the taser. Canadian courts treat excessive force used to apprehend a suspect very seriously in many cases, considering it to be a breach of the accused's Charter rights. A finding of such a breach should lead to a stay of criminal proceedings, a reduction in sentence in some cases, and the exclusion of evidence in others. Police officers are also not immune from criminal prosecution for excessive use of force. Besides, while police officers are absolved of personal civil liability for any tort committed by an officer if she or he acts in good faith and within the scope of her or his duties, municipal and police boards are not excused from responsibility.

Careful consideration of these issues should allow law enforcement agencies to limit their officers' exposure to legal liability and to respond effectively to public concerns about the use of the CEW. 